\title{
コロイド相互作用による構造制御
}

\section{川几 春易}

Haruma Kawaguchi, 慶応義塾大学理 T 学部

\section{1. ラテックスの規則構造}

サブミクロンサイズの高分子微粒子およびその分散 液をここではそれぞれ，ラテックス粒子およびラテッ クスとよぶことにする。分散媒は特に断らない限り水 である。ラテックス中でラテックス粒子が形成する構 造，およびラテックスから分散媒を除去したときにラ テックス粒子自体が作る集合体の構造と, それらの制 御について述べる。

ラテックスを濃縮していくと, 連続相が減少し, や がて粒子が充てんされた状態になる，粒子径がそろっ ていると面心立方格子の充てん構造が得られる。この 濃縮過程は気体状態から液体状態を経て結晶状態に転 移する過程になぞらえられる。ラテックスは白濁状態 から最後は虹彩を放つものに変わる。虹彩は粒子の規 則的配列によって生じる可視光線のブラッグ反射によ る.

このような規則構造は固形分率が $70 \%$ を超えない と得られないと想像されるかもしれない。しかし実 は, その $1 / 100$ 以下の固形分濃度でもそれが可能であ る。これは次の実験で簡単に確かめられる. 希薄ラテ ックスを透析膜のチューブに入れ純水に対して透析し ていくと，まず下層から虹彩が認められるようにな り,それがしだいに上方に拡大していく。透析の過程 では, 浸透圧効果により透析チューブ内のラテックス はむしろ水で希釈される。にもかかわらず結晶構造が 形成されるのは, 連続相である水が大量に粒子に束縛 され，水を抱元込んだ粒子がマクロな動きを封じられ た充てん構造をとったためと解秎される。

蓮らは,このようにラテックスの透析を経て得られ た粒子の規則配列構造を金属䫒微鏡で確認した ${ }^{1), 2)}$.

\section{Structure Control by Colloidal Interactions}

規則構造中には欠陥が存在すること, 規則構造が不規 則構造と共存しその界面が搖動していることなども認 められた (図 1) ${ }^{2)}$. 伊勢らは, 高い荷電を有するラテ ックス粒子を一種の高分子イオンとして扱い, 視覚的 に確認できるラテックス系の規則・不規則構造共存状 態を, 高分子イオン系の濃縮相・希薄相の共存状態の 具象として注目している.ビデオにより, 規則構造中 のボイド周辺の粒子の特異な動きを観察し,また, 規 則構造中と不規則構造中の粒子の動きを比較し, それ らの結果から，粒子に働く力を検討した ${ }^{3)}$.これらの 観察では容器の面の影響が懸念されたが, レーザース キャン顕微鏡での観察によれば容器面から数十 $\mu \mathrm{m}$ 離 れたところでも壁面と同様の構造が形成されてい た ${ }^{4)}$.一方, 大久保は, 単分散シリカコロイドやポリ スチレンラテックスを徹底的にイオン交換し，0.1\% 付近やそれ以下の固形分濃度の分散液中に最大 $8 \mathrm{~mm}$ にも達する巨大な美しい規則構造の結晶の形成を観察 した5)。結晶にはガラス壁から生長したものと, 均一 相から発生したものとがあり, 形態は四面体を主に立 方体などさまざまであった．結晶型はふつう面心立方 であるが充てんが緩むと体心立方もできる。これらの 結晶構造はせん断力が加えられると容易に壊れること から，その弾性率はかなり小さいことがうかがえた。 この結晶構造は当然重力によっても影響を受け格子間 距離は重力や遠心力の関数になる6).

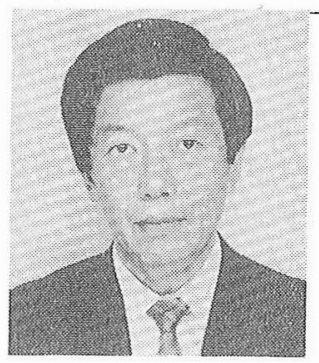

川口春馬 慶応義塾大学理工学 部応用化学科 (223 横浜市港北 区日吉 3-14-1) 教授, 工博 1968年慶大大学院修士課程修 了. 1969 年慶大助手, 1973 年慶 大大学院博士課程中退, 1978 年 〜1979年マサチューセッツ州立 大. 1989年より慶応大教授。專 門は乳化重合, ポリマーコロイ ド，ゲル，医用高分子。 


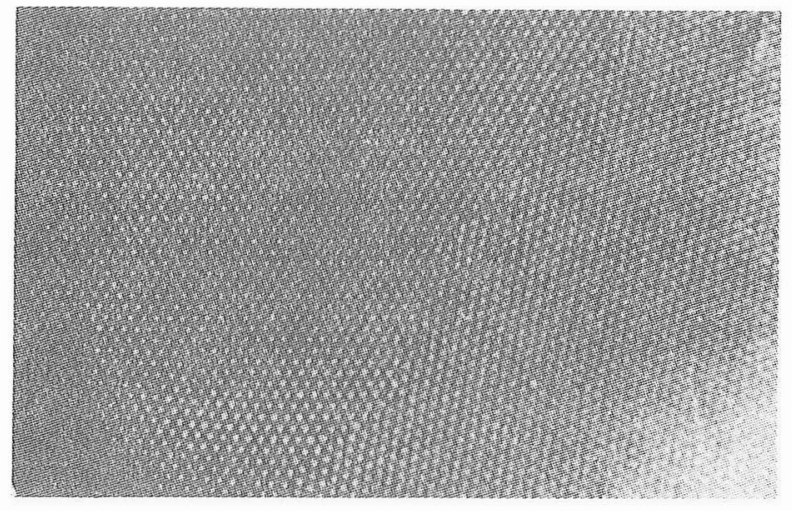

図 1 ラテックス粒子の配列構造 ${ }^{2)}$

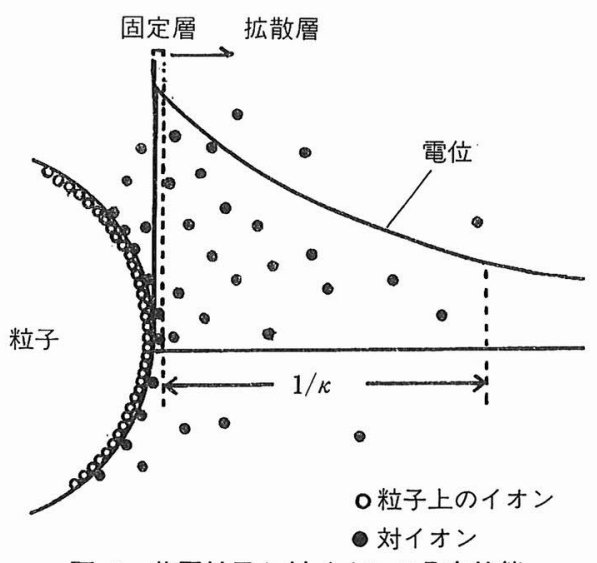

図 2 荷電粒子と対イオンの分布状態
このように, 干渉や回折の測定以外に直接視覚的に 粒子の規則構造が確認されているが, 規則構造が不規 則構造と共存できることの機構については, 従来の解 釈に異論が唱えられ, 現在その吟味がなされていると ころである. 解釈の違いは, 粒子間に働く力の評価の 違いに由来する。そこで粒子間力を吟味する。

\section{2. 粒子間に働く力}

まず従来のコロイド科学であげられる粒子間力につ いて述べる。図 2 に示すように, 荷電粒子の周囲には 対イオンが勾配をもって分布している. 対イオンの分 布を示す尺度としてデバイ長 $1 /$ かが用いられる。こ の值が大きい浪ど粒子の電荷の影響が遠距離まで及ん でいることになる。1/火は（1）式に示すように共存 電解質の種類と量に左右される。粒子間に働く静電斥 力 $V_{\mathrm{R}}$ は当然 $1 / \varkappa$ の関数であり (2) 式で示される.

$1 / x=\left(4 \pi e^{2} \Sigma z_{1}^{2} n_{\mathrm{J}} / \varepsilon k_{\mathrm{B}} T\right)^{-1 / 2}$

$V_{\mathrm{R}}=[\exp (x a) /(1+x a)]^{2}\left(z^{2} e^{2} / 4 \pi \varepsilon r\right) \exp (-x r)$

ここで $e$ は電気素量, $z_{1}$ はイオン $\mathrm{i}$ の価数, $n_{1}$ はフ リーイオン i の濃度, $\varepsilon$ は分散媒の誘電率, $k_{\mathrm{B}}$ はボル ツマン定数, $T$ は絶対温度, $a$ は粒子半径, $r$ は粒子 間距離を表わす:

一方, 粒子の間にはファンデルワールス引力 $V_{\mathrm{A}}$ が 存在する.

$$
\begin{aligned}
V_{\mathrm{A}}=- & A\left\{2 /\left[(r / a)^{2}-1\right]+2(a / r)^{2}\right. \\
+ & \left.\ln \left[1-4(a / r)^{2}\right]\right\} / 6
\end{aligned}
$$

ここで $A$ はハマーカー定数である。

$V_{\mathrm{R}}$ と $V_{\mathrm{A}}$ のバランスで粒子間の相互作用が決まる とするのがいわゆる DLVO 理論である，安定な分散 系では, 優勢な $V_{\mathrm{R}}$ を反映して大きなエネルギー障壁 が存在し，粒子の接近・凝集が抑えられると説明され る.エネルギー障壁の遠距離側に第二次極小とよばれ
る小さなエネルギーの谷が存在することがあるが，そ もそも $V_{\mathrm{A}}$ の及ぶ範囲は $100 \AA$ 以内であり, 第二次極 小は粒子の周期構造形成を説明できるものではない。

表面に溶媒和層を持つ粒子の場合には, 粒子が接近 すると溶媒和層が重なる。重なった部分では溶媒和状 態が平衡からずれエンタルピーが増大し, かつ, 溶媒 和高分子鎖のエントロピーが減少する。そのような不 安定状態を忌避するように重なりを解く形で粒子間反 発力が生まれる。いわゆる立体因子 $V_{\mathrm{S}}$ であり，(4) 式で示される7).

$$
V_{\mathrm{s}}=\pi K \mathrm{~d} a \exp [-(r-2 a) / d]
$$

ここで, $K$ は定数で, $d$ は decay length を示す. 巧妙な装置で粒子間に生じる全ポテンシャル $\left(V_{\mathrm{R}}+\right.$ $\left.V_{\mathrm{A}}+V_{\mathrm{S}}\right)$ を測定できるようになった

溶媒和層を作る高分子鎖は，粒子表面から延び出た もの，粒子に吸着したもの，どちらでもよい. ラテッ クスに加えられた溶解性高分子が吸着溶媒和層を作ら ないとき，新たな粒子間引力を与えることがある，図 $3^{9)}$ に示すように，溶存高分子がある広がりをもって 近接する粒子にまつわりつくと他の溶存高分子が入り 込めない領域ができる。その領域ではバルク相と比べ 高分子濃度が低いので浸透圧差が生じ，その差を減ら すように高分子希薄領域内の水がバルク相に向け動く ため粒子間に引力が生じるというものである。これに より粒子の凝集や規則構造の形成が起り得る ${ }^{97-12)}$. そのためには当然, 適量の高分子濃度が存在する。こ れらはデプレッション（枯渴）効果または体積制限効 果とよばれるが，上に述べたタイプの凝集は高分子に よる粒子間のブリッデングによって起こり得ると考 え,デプレッション効果を否定する見方もある。なお 粒子間にまたがる高分子の吸着と見なされるブリッヂ ングは，従来から存在を指摘されながら定量的な評価 


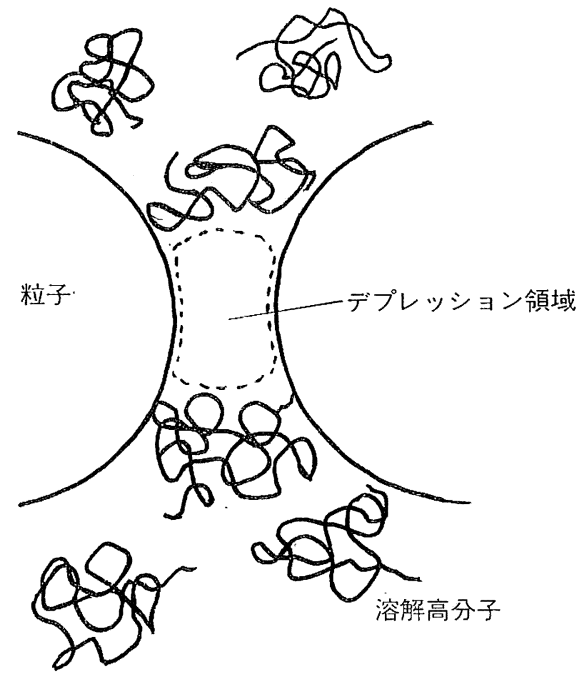

図 3 デプレッション効果

が進んでいない.

多くの場合, 粒子の規則配列構造は不規則構造と共 存している．長距離はなれた粒子間に斥力だけしか働 かないとすればすべての粒子は互いに最もはなれた位 置をとって分布し，規則構造と不規則構造の共存はあ りえないことになるとの考えは不合理とはいえない. そこに, “同符号荷電粒子間にも長距離静電引力が存 在する”という提唱が生まれた ${ }^{13)}$ 。

\section{3. 規則構造・不規則構造の共存の解釈}

この同符号荷電粒子間静電引力の主張は, これまで 信奉されてきた DLVO 理論の否定である. 伊勢は, 引力の起源が粒子間の対イオンにあると考元, 対イオ ンと粒子間の引力が同符号電荷粒子を引きつける力と なっていると主張し，いくつかの論拠を示した ${ }^{13)}$. 例 えば，ラテックスの規則構造の大型化が，いわゆる Ostwald 熟成則に従って進むことも粒子間静電引力 の存在を支持することとしてあげている ${ }^{14)}$. 静電引力 説は曽我見の理論 ${ }^{15)}$ を定量的な根拠としているが, Overbeek はその式に修正を加えた ${ }^{16)}$.

粒子間に別の機構で引力が働くとの考えもある. 粒 子のブラウン運動により粒子の荷電の中心と対イオン 雲囲気の中心とがずれて, それにより, 原子間の分散 力のような引力が粒子間に働き濃縮相ができるという 考えである ${ }^{17)}$.ここでは, 粒子のブラウン運動が長距 離引力を引き出せるだけの十分な摇らぎをもつものか 定量的な検討が必要である。

粒子間静電引力を想定せずに規則構造 ・ 不規則構造 の共存を説明できるとする考えの内の代表的なもの
は，“アルダー転移”説である18),19)。アルダー転移 は, 引力をもたない粒子同士でも密度があるレベルを 超えると濃厚な規則構造相と希薄な不規則構造相に相 分離し二相共存が実現するというものである.それに よれば，分散系で粒子の体積分率 $(\Phi)$ を高めていく と $\emptyset \fallingdotseq 0.50$ で結晶相が生成し始め不規則相と共存し, $\Phi \doteqdot 0.55$ で結晶化がほほ完結することになる。 さらに増していくと結晶型が変化する。したがって, ラテックスに扔ける規則構造・不規則構造の共存がア ルダー転移によって説明できるか否かの判定には, ま ず二相共存系の Фのチェックをすることが必要であ る.ただし， Фは固体粒子そのものの体積分率では なく, 対イオン層を含んだ有効径に基づくものであ る. 有効径 $=($ 粒子半径+デバイ長) としてよいかに ついては議論が分かれるが，希薄ラテックスがイオン 交換に伴って粒子間距離の大きな結晶を生成していく 現象などの説明にはデバイ長支配説は分かりやすい. （2）式で示すようにデバイ長は脱イオンの度合いによ り幅広く調整できる。脱イオンを徹底的に行い分厚い デバイ長を導入した系では, 粒子径に多少分布があっ ても乱れのない結晶構造を作ることができる。これま でにいくつかの手法で不規則構造/規則構造およびそ の中の結晶型に関する相図が求められている20) 22). それらは大旨アルダー転移の適用の妥当性を支持する ものである.Vanderhoff らは, 粒子間静電斥力の効 果をいっそう大きく考慮した構造形成機構を提唱し た ${ }^{23)}$.

諸現象を静電斥力だけで説明できるとする立場と， 遠距離引力が不可欠とする立場との間で, 現在も両理 論の比較・吟味が進められているが, 例えばラテック スの弾性率の実験結果のように両理論に優劣を与えな いケースもあり，なかなか帰趨が見えてこない.

\section{4. 粒子集合体の規則構造}

適当な濃度の単分散ラテックスを適量ガラス板上な どに展開し乾燥させると, 粒子が二次元に規則配列し たものを得ることができる，林らは，直径 $1.5 \mu \mathrm{m}$ の ポリスチレンラテックス粒子でそのような微小レンズ の集合体，換言すれば，昆虫の複眼儗せられるもの を作製した ${ }^{24)}$. この二次元構造を 2 面重ねると，モア レ縞が観察できる。東谷らは半透膜上にラテックス粒 子を沈着させ二次元規則構造を作り, 膜と粒子間の相 互作用が構造を決定することを示した ${ }^{25)}$. 下限臨界共 溶温度（LCST）を有し低温で水和し高温で脱水和す るポリーNーイソプロピルアクリルアミドからなるシ エル層をもつ粒子を板上に沈着させるとシェルの厚さ に相当する粒子間隙を空けて配列構造を作ることがで 
きる26).これは，化学的のみならず物理的にもミク口 異相構造をもち，それが温度応答性を示す材料として 特徴を発揮する。

福富らは単分散硬質粒子からなるラテックスのキャ ス卜膜を作り，膜の構造すなわち膜中の粒子の配列の パターンを検討している27)。分散液の場合と異なり, 未精製ラテックスからでも粒子はかなり規則的な配列 構造をとって累積する。この場合も面心立方構造がで きやすい。粒子を架橋し不動化すると孔径がそろった 通路をもつ多孔体に相当するものができる.

種々の大きさの単分散ラテックス粒子が再現性よく 調製できるようになったことから，今後さらに特徴を もつ規則構造粒子集合材料が作られ利用されるように なっていくであろう。

\section{文 献}

1) A. Kose, M. Ozaki, K. Takano, Y. Kobayashi, S. Hachisu: J. Colloid Interface Sci., 44, 330 (1973)

2）蓮 精: 表面, 14, 15 (1976)

3) N. Ise, H. Matsuoka, K. Ito, H. Yoshida: Faraday Discuss. Chem. Soc., 90, 153 (1990)

4) N. Ise, K. Ito, H. Yoshida: Polym. Prepr., 33, 769 (1992)

5) T. Okubo: Naturwissenschaften, 79, 317 (1992)

6) T. Okubo: J. Am. Chem. Soc., 112, 5420 (1990)

7) G.H. Bogush, C.F. Zukoski IV: J. Colloid Interface Sci., 142, 19 (1991)

8) J. Klein: J. Chem. Soc., Faraday Trans., 77, 77 (1983)

9) T. Nashima, K. Furusawa : Colloids Surfaces, 55, 149 (1991)
10）古沢邦夫 : ケミカルエンジニヤリング, 1992 年 7 月, p. 33

11) B. Vincent, J. Edwards, S. Emmett, A. Jones: Colloids Surfaces, 18, 261 (1986)

12) P.D. Patel, W.B. Russel: J. Colloid Interface Sci., 131, 192 (1989)

13) N. Ise: Angew. Chem. Int. Ed. Engl., 25, 323 (1986)

14) N. Ise, H. Matsuoka, K. Ito, H. Yoshida, J. Yamanaka: Langmuir, 6, 296 (1990)

15) I. Sogami : Phys. Lett., A96, 199 (1983)

16) J.T.G. Overbeek: J. Chem. Phys., 87, 4406 (1987)

17) S. Yoshino: in "Ordering and Organization in ionic solutions" World Sci. Publishing Co., Singapore (1989) p.449

18) S. Hachisu, Y. Kobayashi: J. Colloid Interface Sci., 42, 342 (1973)

19) K. Takano, S. Hachisu: J. Chem. Phys., 67, 2604 (1977)

20) T. Okubo: J. Chem. Phys., 95, 3690 (1991)

21) P.N. Pusey, W. van Megen : in "Physics of complex and supermolecular fluids" Exxon Monograph (1985) pp.673 698

22) L.P. Voegtli, C.F. Zukoski IV : J. Colloid Interface Sci., 141, 79 (1991)

23) P.R. Krumrine, J.W. Vanderhoff : in "Polymer Colloids II" Plenum, Now York (1980) p.289

24）林 貞夫：高分子, 39, 222 (1990)

25) K. Higashitani, K. Hata, Y. Okanaka, K. Ueshima : J. Chem. Engr. Jpn., 24, 346 (1991)

26）尾島理佳, 藤本啓二, 川口春馬 : Polym. Prepr.Jpn., 40, 4090 (1991)

27) G.H. Ma, T. Fukutomi : Macromol., 25, 1870 (1992)

\section{「高分子機能材料シリーズ」}

\section{編 集 高分子学会 発 行 共立出版(侏) \\ 体裁 A 5 判定価 12,360 円（税込み）} 会員割引価格 11,000 円（税・送料込み）

第 1 巻二高分子の合成と反応 (1) : 序論 /ラジカル 重合/イオン重合／配位重合/その他の重合

第 2 巻二高分子の合成と反応 (2)：序論／開環重 合/へテロ多重結合モノマーの重合／重縮合／重付 加 /付加縮合 /その他の重合 /高分子反応

第 3 巻二高分子の物性の基礎：序論／溶液物性／溶 融体物性／固体物性／特性解析

第 5 巻二電子機能材料：序論 /絶縁材料／誘電材 料／導電材料／イオン伝導材料／超伝導材料／磁性 材料

第 $\mathbf{6}$ 巻=光機能材料 : 序論 $/$ 光励起状態の物理と化 学 /光学材料 /光変換材料 /感光材料 / 情報記録材 料
第 7 巻 $=$ 分離 - 輸送機能材料：序論 $/$ 分離 - 輸送系 の基礎と設計 $/$ 気体分離 $/$ 液一液

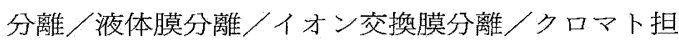
体 /分子認識と応答機能 /繊維工業と分離機能 $/$ 環 境問題と分離技術

第 9 巻=医療機能材料：序論／高分子と生体系との 相互作用／生体適合性材料／人工臓器用材料／診断 用高分子材料 /ドラッグデリバリーシステム／材料 の安全性評価

〈続刊〉（）内発行予定月

第 4 巻 (2月) =高分子集合体の形成と性質：序 論／高分子コンプレックス／高分子ゲル／高分子分 散系／高分子液晶／有機薄膜／表面・薄膜特性解析 第 8 巻 (5月) =生命工学材料：序論 /タンパク質 工学と材料／細胞工学と材料／バイオミメティック ス材料

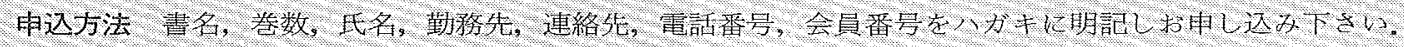
申込先 [104] 東点都中央区築地 2-4-2 高分子学会 出版係 2003-3543-3772 Fax 03-3545-8560 